\title{
Photosynthetic Activity of Cassava Plants under Weed COMPETITION $^{1}$
}

\author{
Atividade Fotossintética de Plantas de Mandioca Submetidas a Competição com Plantas \\ Daninhas
}

\author{
ASPIAZÜ, I. ${ }^{2}$, SEDIYAMA, T. ${ }^{3}$, RIBEIRO JR., J.I. ${ }^{4}$, SILVA, A.A. ${ }^{3}$, CONCENCO, G. ${ }^{4}$, FERREIRA, E.A. ${ }^{6}$, \\ GALON, L. ${ }^{7}$, SILVA, A.F. ${ }^{8}$, BORGES, E.T. ${ }^{9}$ e ARAUJO, W.F. ${ }^{10}$
}

\begin{abstract}
The objective of this work was to evaluate characteristics associated with the photosynthetic activity of cassava plants under weed competition. The trial was carried out under field conditions, and experimental units consisted of $150 \mathrm{dm}^{3}$ fiberglass boxes containing red yellow Latosol, previously corrected and fertilized. Treatments consisted in the cultivation of cassava plants which were free of weed competition and associated with three weed species: Bidens pilosa, Commelina benghalensis or Brachiaria plantaginea. After manioc sprouting started, 15 days after being planted, weeds that had been sown when manioc was planted were thinned, there were then eight plants left per experimental unit in accordance with specified treatments: cassava free of competition, cassava competing with $B$. pilosa, cassava competing with $C$. benghalensis and cassava competing with $B$. plantaginea. Sixty days after crop emergence leaf internal $\mathrm{CO}_{2}$ concentration (Ci), leaf temperature at the time of evaluation $\left(\mathrm{T}_{\text {leaf }}\right)$ and photosynthetic rate (A) were evaluated, also the $\mathrm{CO}_{2}$ consumption rate $(\Delta \mathrm{C})$ of cassava plants was calculated. A correlation matrix between variables was also obtained. All characteristics associated with photosynthesis in cassava plants were influenced by weed species. Cassava was more affected by $B$. pilosa and $B$. plantaginea in which concerns its exposition to solar radiation and water, while $C$. benghalensis seems to mostly affect the composition of incident light on the culture, allowing cassava to anticipate imposition when competing, even before it reaches harmful levels.
\end{abstract}

Keywords: interference, Bidens pilosa, Commelina benghalensis, Brachiaria plantaginea, physiological variables.

\begin{abstract}
RESUMO - Objetivou-se com este trabalho avaliar caracteristicas associadas à atividade fotossintética de plantas de mandioca sob competição ou não com plantas daninhas. O experimento foi realizado em condições de ambiente aberto, sendo as unidades experimentais compostas por vasos de fibra de vidro de $150 \mathrm{dm}^{3}$ preenchidos com Latossolo Vermelho Amarelo, previamente adubado. Os tratamentos consistiram no cultivo de plantas de mandioca isoladas e associadas a três espécies daninhas (Bidens pilosa, Commelina benghalensis e Brachiaria plantaginea). Após início da brotação das manivas, 15 dias após o plantio, fez-se o desbaste das plantas daninhas, semeadas no momento do plantio das manivas, deixando-se oito plantas de B. pilosa, quatro de C. benghalensis e quatro de B. plantaginea. Aos 60 dias após a brotação das manivas, avaliou-se a concentração de $\mathrm{CO}_{2}$ interna na folha (Ci), temperatura da folha no momento da avaliação ( $\left.T_{\text {leaf }}\right)$ e a taxa fotossintética (A), sendo calculado também o $\mathrm{CO}_{2}$ consumido $(\Delta C)$ referentes às plantas de mandioca. Foi elaborada ainda matriz de correlação entre as variáveis. Todas as caracteristicas avaliadas foram influenciadas
\end{abstract}

1 Recebido para publicação em 21.8.2009 e na forma revisada em 17.12.2010.

${ }^{2}$ Eng $^{-}-$Agr $^{0}$., D.Sc., Professor da Universidade Estadual de Montes Claros - UNIMONTES, Janaúba-MG, <aspiazu@gmail.com>; ${ }^{3}$ Engo-Agr ${ }^{\circ}$., D.Sc., Professor do Dep. de Fitotecnia, Univesrsidade Federal de Viçosa - DFT/UFV, 36570-000 Viçosa-MG; ${ }^{4}$ Engo-Agr ${ }^{\circ}$., D.Sc., Prof. do Dep. de Estatística, DPE/UFV; ${ }^{5}$ Eng $^{0}-A_{\text {gr }}{ }^{0}$., D.Sc., Valmont Industries, Inc. USA. Valmont Industries - Irrigation Division, 7002 North 288th Street, P.O. Box 358, Valley, NE 68064 USA; ${ }^{6}$ Eng$^{0}$-Agr ${ }^{\circ}$., D. Sc., Bolsista PNPD Universidade Federal

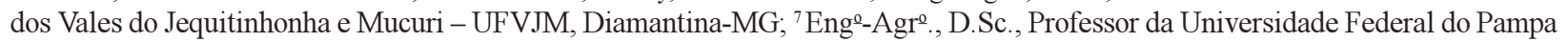
- UNIPAMPA, Itaqui-RS; ${ }^{8}$ Engo-Agro ${ }^{-}$, D.Sc., Weed Management Lead, CanaVialis e Alellyx, Alellyx Applied Genomics. Rua James Clerk Maxwell, 320, 13069-380 Campinas-SP, Brazil; ${ }^{9}$ Estudante de graduação do curso de agronomia, UFV, bolsista iniciação científica; ${ }^{10}$ Engo-Agr ${ }^{\circ}$., D. Sc., Prof. da Universidade Federal de Roraima - UFRR, Boa Vista-RR.

Planta Daninha, Viçosa-MG, v. 28, p. 963-968, 2010. Número Especial 
pela espécie de planta daninha em competição com a cultura. A mandioca foi mais afetada por $\boldsymbol{B}$. pilosa e B. plantaginea em relação ao acesso à radiação solar é água, enquanto $\boldsymbol{C}$. benghalensis parece afetar mais a composição da luz incidente sobre a cultura, permitindo que a mandioca possa antecipar a imposição da competição, mesmo antes que atinja niveis prejudiciais

Palavras-chave: interferência, Bidens pilosa, Commelina benghalensis, Brachiaria plantaginea, variáveis fisiológicas.

\section{INTRODUCTION}

Interspecific and intraspecific plant competition affect the amount and the quality of the final product, as well as its efficiency in utilization of environmental resources (VanderZee \& Kennedy, 1983; Melo et al., 2006). This is noted when assessing physiological characteristics associated to photosynthesis, such as concentration of internal and external gases (Kirschbaum \& Pearcy, 1988), light composition and intensity (Sharkey \& Raschke, 1981) and mass accumulation by plants under different conditions.

Although gas exchange capability by stomata is considered a main limitation for photosynthetic $\mathrm{CO}_{2}$ assimilation (Hutmacher $\&$ Krieg, 1983), it is unlikely that gas exchange will limit the rate of photosynthesis when interacting with other factors. However, photosynthetic rate is directly related to the photosynthetically active radiation (composition of light), to water availability and gas exchange (Naves-Barbiero et al., 2000). Plants have specific needs for light, predominantly in bands of red and blue (Messinger et al., 2006). When plants do not receive these wave lengths in a satisfactory manner, they need to adapt themselves in order to survive (Attridge, 1990). When under competition for light, the red and far-red ratio affected by shading is also important (Weller et al., 1997) and influences photosynthetic efficiency (Da Matta et al., 2001).

The objective of this work was to evaluate characteristics associated to the photosynthetic activity of cassava plants under weed competition.

\section{MATERIAL AND METHODS}

The trial was conducted in the Experimental Field Professor Diogo Alves de
Mello, Departmento de Fitotecnia (DFT, Universidade Federal de Viçosa (UFV), Brazil. The experimental units were fiberglass vases with capacity for $150 \mathrm{dm}^{3}$ of Red Yellow Latosol previously fertilized according to recommendations of Cantarutti et al. (2007). All vases were drilled at the bottom and filled with $5 \mathrm{~cm}$ of crushed stone before being filled with soil, in order to drain the excess of water from rain or irrigation. Throughout the experimental period, soil moisture was kept at about $2 / 3$ of field capacity by periodical irrigation according to the needs.

One cassava stem cutting of about $15 \mathrm{~cm}$ in length was planted in each plot for the experiment, as well as weeds, according to treatments. When cassava emerged weeds were standardized to such desired densities: Bidens pilosa (three plants $\mathrm{m}^{-2}$ ), Brachiaria plantaginea ( $\mathrm{six}$ plants $\mathrm{m}^{-2}$ ) or Commelina benghalensis (transplanted by seedlings - three plants $\mathrm{m}^{-2}$ ). The experimental design was completely randomized blocks with three replications, in a $3 \times 8$ factorial scheme. Weeds from soil seed bank were removed manually every week. Weed densities on the experimental units were defined by consulting experts in this area.

Sixty days after crop emergence (DCE), physiological parameters were evaluated by using an Infrared Gas Analyzer (LCA-4 ADC Bioscientific, Herts, UK). These tests were performed in the younger fully expanded cassava leaf, between 8:00 and 10:00a.m. Only one block was evaluated per day, in order to maintain environmental conditions as homogeneous as possible. Leaf internal $\mathrm{CO}_{2}$ concentration $\left(\mathrm{Ci}-\mu \mathrm{mol} \mathrm{mol}^{-1}\right)$, leaf temperature at the evaluation time (Tleaf $-{ }^{\circ} \mathrm{C}$ ) and photosynthetic rate $\left(\mathrm{A}-\mu \mathrm{mol} \mathrm{m} \mathrm{m}^{-2} \mathrm{~s}^{-1}\right)$ were evaluated, and $\mathrm{CO}_{2}$ consumption $(\Delta \mathrm{C}$ $\mu \mathrm{mol} \mathrm{mol}^{-1}$ ) was calculated from the reference values of $\mathrm{CO}_{2}$ and $\mathrm{CO}_{2}$ inside the evaluation chamber. 
Data were submitted to analysis of variance through F-test, and when there was significance means, they were then compared in pairs through the test of least significant difference (LSD). All tests were performed at $5 \%$ level using the statistical software SAEG. Among the variables studied, Pearson correlations were calculated between evaluated parameters, and tested through t-test.

\section{RESULTS AND DISCUSSION}

Cassava plants grown free of competition showed greater $(\mathrm{P}<0.05)$ leaf internal $\mathrm{CO}_{2}$ concentration ( $\mathrm{Ci}$ ) than when competing with weeds (Table 1). Lower $\mathrm{CO}_{2}$ concentrations $(\mathrm{P}<0.05)$ in leaves were observed when cassava plants were grown under competition with $C$. benghalensis. $\mathrm{Ci}$ is considered a physiological variable, influenced by species, but also highly dependent on environmental factors such as availability of water and light, among others (Ometto et al., 2003). The highest values $(\mathrm{P}<0.05)$ for $\mathrm{Ci}$ observed in cassava plantswere when under competition with B. pilosa or B. plantaginea, if compared to $C$. benghalensis. That can be attributed to the accelerated plant metabolism as a way to increase growth rate and escape shading caused by weeds. It is believed that under these conditions, where lower $\mathrm{Ci}$ occurs, $\mathrm{CO}_{2}$ was consumed due to the increase in the metabolic rate. The effect of $C$. benghalensis on $\mathrm{Ci}$ of cassava plants was not very striking, since it only motivated cassava to recognize its imposition in competition, and stimulate its metabolism in order to increase its competitive capacity.
The quality of light regulates many processes in plants, such as germination, morphogenesis and flowering (Young \& Smith, 1989; Ballaré et al., 1992). The morphological responses are well known and include pronounced stem elongation, reduction in dry weight proportion of leaf/stem, and reduction in tillering. It has been shown that these responses are triggered by phytochrome in response to low Red:Far Red (R:FR) ratios in the canopy (Smith, 1982). Researches conducted by Ballaré, Young and colleagues showed that responses to changes in R:FR ratios occur before the mutual shading among neighbors. Based on that work, it was proposed that the Far Red radiation, which is reflected by adjacent leaves, is a means of early detection that signals the imminence of competition during canopy development (Ballaré et al., 1990, 1992; Holt, 1995; Merotto Jr. et al., 2009). In addition, some species are capable of recognizing others by the amount of radiation reflected in each wave length (Larcher, 2006). It was probably what happened when cassava plants competed with $C$. benghalensis; the presence of this weed species might have been simply enough to increase cassava metabolism as a way to avoid the imposition of future competition. Since resources such as light $B$. Pilosa and B. plantaginea show rapid growth and high capacity to consume environment resources efficiently, while $C$. benghalensis, is a species that survives in less disturbed environments. According to Grime (1979), competition is a way neighboring plants use the same resources, and success in competition is strongly determined by the plant capacity to capture these resources. Thus, a good competitor has a high relative growth rate

Table 1 - Characteristics associated with cassava plants use of water 60 days after emergence, in function of weed infestation. ViçosaMG, 2008

\begin{tabular}{|l|c|c|c|c|}
\hline \multicolumn{1}{|c|}{ Treatment } & $\begin{array}{c}\mathrm{Ci} \\
\left(\mu \mathrm{mol} \mathrm{mol}^{-1}\right)\end{array}$ & $\begin{array}{c}\Delta \mathrm{C} \\
\left(\mu \mathrm{mol} \mathrm{mol}{ }^{-1}\right)\end{array}$ & $\begin{array}{c}\mathrm{T}_{\text {leaf }} \\
\left({ }^{\circ} \mathrm{C}\right)\end{array}$ & $\begin{array}{c}\mathrm{A} \\
\left(\mu \mathrm{mol} \mathrm{m}^{-2} \mathrm{~s}^{-1}\right)\end{array}$ \\
\hline Cassava & $295,7 \mathrm{a} \mathrm{a}^{1 /}$ & $14,43 \mathrm{~b}$ & $32,1 \mathrm{~b}$ & $5,71 \mathrm{~b}$ \\
\hline Cassava $\times$ B. pilosa & $256,4 \mathrm{~b}$ & $12,73 \mathrm{~b}$ & $33,6 \mathrm{ab}$ & $5,17 \mathrm{~b}$ \\
\hline Cassava x C. benghalensis & $232,3 \mathrm{c}$ & $19,60 \mathrm{a}$ & $35,1 \mathrm{a}$ & $7,32 \mathrm{a}$ \\
\hline Cassava x B. plantaginea & $266,9 \mathrm{~b}$ & $14,50 \mathrm{~b}$ & $33,6 \mathrm{ab}$ & $5,93 \mathrm{~b}$ \\
\hline CV $(\%)$ & 10,0 & 19,4 & 3,6 & 15,2 \\
\hline
\end{tabular}

$1 /$ Means followed by same letter, in same column, do not differ through Fisher's LSD test at $5 \%$ probability. $\mathrm{Ci}=1$ eaf internal $\mathrm{CO}_{2}$ concentration; $\Delta \mathrm{C}=\mathrm{CO}_{2}$ consumed during evaluation; $\mathrm{T}_{\text {leaf }}=$ leaf temperature; $\mathrm{A}=$ photosynthetic rate. 
and can use the available resources quickly. However, Tilman (1980) claims that competitive success is the ability to extract scarce resources and to tolerate this lack of resources. Therefore, in theory, a good competitor could be the species with least resource requirement (Radosevich et al., 1997).

Light affects stomatal opening indirectly through its effect on $\mathrm{CO}_{2}$ assimilation (Sharkey \& Raschke, 1981; Nishio et al., 1994). However, stomatal opening is less dependent on $\mathrm{Ci}$, and responds directly to light (Radosevich, 1997). Thus, under competing and shading conditions, the stability of light is involved in controlling stomatal opening, as well as the balance between the gas in the interior of the leaf and on the environment (Tallman \& Zeiger, 1988; Loreto \& Bongi, 1989). In studies with sunflower plants subjected to water stress, leaf internal $\mathrm{CO}_{2}$ concentration (Ci) increased, while the photosynthetic rate (A) reduced. When the stress agent was removed, the plant recovered, and both photosynthetic capacity and $\mathrm{Ci}$ were normalized (Corniani et al., 2006).

The consumption of $\mathrm{CO}_{2}(\Delta \mathrm{C})$ increased proportionally to the decrease of $\mathrm{Ci}$. That means that the higher the $\Delta \mathrm{C}$ in the mesophyll, the higher the gradient created between the interior of the leaf and the environment. When the three weeds were compared, $C$. benghalensis was the one that least $(\mathrm{P}<0.05)$ affected cassava plant consumption of $\mathrm{CO}_{2}$ because there was a higher gradient between the internal and the external sides of the cassava leaves. This is due mainly to the metabolism stimulus caused by low competition between crop and weeds. $B$. pilosa and B. plantaginea, on the other hand, it affected cassava plant in a way that, even under competition, and when their metabolism should have been stimulated, no differences were observed $(\mathrm{P}>0.05)$ regarding the competition-free control.

Cassava leaves temperature was higher when in competition with $C$. benghalensis, mainly due to the stimulus in metabolism caused by the presence of weed, and due to the low competition exerted, or simply due to the changing of the quality of light, which allowed cassava plants to recognize the species of weed (Radosevich et al., 1997; Larcher, 2006). The competition-free control indicates the metabolic rate usual to cassava plants when free of competition. In this situation, plant growth becomes more balanced, distributing photoassimilates proportionally between shoots and roots, which is not the case when under competition (Radosevich et al., 1997). Plant metabolism causes an increase in leaf temperature, therefore leaf temperature is usually higher than the temperature of the air around it. Thus, metabolism increases can be indirectly measured as a function of leaf temperature. The difference between leaf temperature and the air around it is commonly only 1 or $2^{\circ} \mathrm{C}$, but in extreme cases it may exceed $5^{\circ} \mathrm{C}$ (Atkin et al., 2000). Cassava plants under competition with $B$. pilosa or $B$. plantaginea stayed half way compared to the ones observed in weed-free control, and at treatment under competition with C. benghalensis. This indicates that these weeds were able to prevent cassava from reacting adequately to the imposition of competition, probably by limiting crop access to appropriate levels of a given resource, such as light or water, for example.

Photosynthesis, and therefore respiration, depends on the constant flow of $\mathrm{CO}_{2}$ and of $\mathrm{O}_{2}$ in and out of the cell; this free flow is function of the concentration of $\mathrm{CO}_{2}$ and $\mathrm{O}_{2}$ in the intercellular spaces depending on stomatal opening, main controller of the gas flux (Messinger et al., 2006). This, in turn, is largely controlled by turgescence of both guard-cells (which control stomatal opening) and stomatal epidermal cells (Humble \& Hsiao, 1970). Low water potentials induce stomatal closure and reduce leaf conductance,

Table 2 - Pearson linear correlation matrix in function of the characteristics associated with the phtosynthesis of cassava plants 60 days after emergence. Viçosa-MG, 2008

\begin{tabular}{|l|c|c|c|c|}
\hline & $\begin{array}{c}\mathrm{Ci} \\
\left(\mu \mathrm{mol} \mathrm{mol}^{-1}\right)\end{array}$ & $\begin{array}{c}\Delta \mathrm{C} \\
\left(\mu \mathrm{mol} \mathrm{mol}^{-1}\right)\end{array}$ & $\begin{array}{c}\mathrm{T}_{\text {leaf }} \\
\left({ }^{\circ} \mathrm{C}\right)\end{array}$ & $\begin{array}{c}\mathrm{A} \\
\left(\mu \mathrm{mol} \mathrm{m}^{-2} \mathrm{~s}^{-1}\right)\end{array}$ \\
\hline $\mathrm{Ci}$ & - & & & \\
\hline$\Delta \mathrm{C}$ & $-0,60^{*}$ & - & & \\
\hline $\mathrm{T}_{\text {leaf }}$ & $-0,53$ & 0,34 & - & \\
\hline $\mathrm{A}$ & $-0,60^{*}$ & $0,96^{*}$ & 0,37 & - \\
\hline
\end{tabular}

$*=$ significant through $\mathrm{t}$ test $(\mathrm{P}<0,05) . \mathrm{Ci}=$ leaf internal $\mathrm{CO}_{2}$ concentration; $\Delta \mathrm{C}=\mathrm{CO}_{2}$ consumed during evaluation; $\mathrm{T}_{\text {leaf }}=$ leaf temperature; $\mathrm{A}=$ photosynthetic rate. 
inhibiting photosynthesis and transpiration and usually resulting in increased leaf temperature (Attridge, 1990).

The photosynthetic rate was also higher $(\mathrm{P}<0.05)$ for cassava plant under competition with $C$. benghalensis, when compared to other treatments. According to Merotto Jr. et al. (2009), changes in the quality of light caused by weeds is a factor that affects crop development. Photosynthetic rate of cassava under competition with $C$. benghalensis was $7.32 \mu \mathrm{mol} \mathrm{m}{ }^{-2} \mathrm{~s}^{-1} \mathrm{CO}_{2}$, while for the average of the remaining treatments was $5.50 \mu \mathrm{mol} \mathrm{m}^{-2} \mathrm{~s}^{-1}$ $\mathrm{CO}_{2}$. The radiation balance and composition on the plant when in competition or shading, combined with carbohydrate level in leaves, may increase respiratory rate directly or through alternative pathways associated with the respiratory chain (Pystina \& Danilov, 2001). This could make photosynthesis balance even smaller and reduce the ability of the plant to accumulate mass. Several species of weed and commercial crops change their photosynthetic rate at different levels under the same environmental conditions (Procópio et al., 2004).

Generally, thephotosynthetic characteristics of cassava were influenced by its competition with B. pilosa and B. plantaginea. We have noticed that cassava plants are affected by these species of weed especially concerning its exposition to light and water. However, there were no negative effects when cassava plants competed with $C$. benghalensis. This species seems to rather affect the composition of light by reflecting peculiar spectrum of specific wavelengths, which allows cassava plants to anticipate the imposition of competition even before they get to harmful levels.

\section{ACKNOWLEDGEMENTS}

To the Research Foundation of the State of Minas Gerais (FAPEMIG) for financial support for publishing this paper.

\section{LITERATURE CITED}

ATKIN, O. K. et al. Leaf respiration of Snow Gum in the light and dark. Interactions between temperature and irradiance. Plant Physiol., v. 122, n. 3, p. 915-923, 2000.
ATTRIDGE, T. H. The natural light environment. In: ATTRIDGE, T. H. (Ed.). Light and plant responses. London: Edward Arnold, 1990. p. 1-5.

BALLARÉ, C. L.; SCOPEL, A. L.; SÁNCHEZ, R. A. Far-red radiation reflected from adjacent leaves an early signal of competition in plant canopies. Science, v. 247, p. 329-332, 1990 .

BALLARÉ, C. L. et al. Photomorphogenic processes in the agricultural environment. Photochem. Photobiol., v. 56, n. 5, p. 777-788, 1992.

CANTARUTTI, R. B. et al. Avaliação da fertilidade do solo e recomendação de fertilizantes. In: NOVAIS R. F. et al. Fertilidade do solo. Visconde do Rio Branco: Suprema, 2007, v. 1. p. $769-850$.

CASAL, J. J.; SMITH, H. The function, action and adaptive significance of phytochrome in light-grown plants. Plant

Cell Environ., v. 12, n. 9, p. 855-862, 1989.

CORNIANI, N. et al. Determinação das trocas gasosas e de potencial hídrico através do uso de sistemas portáteis na avaliação do estresse. In: SIMPÓSIO INTERNACIONAL DE INICIAÇÃO CIENTÍFICA DA UNIVERSIDADE DE SÃO PAULO, 14., 2006, Piracicaba. Anais. São Paulo: USP, 2006. CD-ROM.

DA MATTA, F. M. et al. Actual and potential photosynthetic rates of tropical crop species. R. Bras. Fisiol. Veg., v. 13, n. 1, p. 24-32, 2001

GRIME, J. P. Plant strategies and vegetation processes. Chichester: John Wiley \& Sons, 1979.

HOLT, J. S. Plant responses to light: a potential tool for weed management. Weed Sci., v. 43, n. 3, p. 474-482, 1995

HUMBLE, G. D.; HSIAO, T. C. Light-dependent influx and efflux of potassium of guard cells during stomatal opening and closing. Plant Physiol., v. 46, n. 3, p. 483-487, 1970.

HUTMACHER, R. B.; KRIEG, D. R. Photosynthetic rate control in cotton. Plant Physiol., v. 73, n. 3, p. 658-661, 1983.

KIRSCHBAUM, M. U. F.; PEARCY, R. W. Gas exchange analysis of the relative importance of stomatal and biochemical factors in phosynthetic induction in Alocasia macrorrhiza. Plant Physiol., v. 86, n. 3, p. 782-785, 1988.

LARCHER, W. Ecofisiologia vegetal. São Carlos: RIMA, 2006. $531 \mathrm{p}$.

LORETO, F.; BONGI, G. Combined low temperature-high light effects on gas exchange properties of jojoba leaves. Plant Physiol., v. 91, n. 4, p. 1580-1585, 1989. 
MELO, P. T. B. S. et al. Comportamento de populações de arroz irrigado em função das proporções de plantas originadas de sementes de alta e baixa qualidade fisiológica. R. Bras. Agroci., v. 12, n. 1, p. 37-43, 2006.

MEROTTO JR., A.; FISHER, A. J.; VIDAL, R. A. Perspectives of light quality knowledge as an advanced ecophysiological weed management tool. Planta Daninha, v. 27, n. 2 , p. $407-419,2009$.

MESSINGER, S. M. et al. Evidence for involvement of photosynthetic processes in the stomatal response to $\mathrm{CO}_{2}$ Plant Physiol., v. 140, n. 2, p. 771-778, 2006

NAVES-BARBIERO, C. C. et al. Fluxo de seiva e condutância estomática de duas espécies lenhosas sempre-verdes no campo sujo e cerradão. R. Bras. Fisiol. Veg., v. 12, n. 2 , p. 119-134, 2000.

NISHIO, J. N.; SUN, J.; VOGELMANN, T. C. Photoinhibition and the light environment within leaves. In: BAKER, N. R.; BOWYER, J. R. (Eds.). Photoinhibition of photosynthesis. Oxford: BIOS Scientific Publishers, 1994. p. $1-24$

OMETTO, J. P. H. B. et al. Variação temporal do isótopo estável do carbono em material arbóreo em florestas da região Amazônica. In: CONGRESSO BRASILEIRO DE ECOLOGIA, 4., 2003, Fortaleza. Anais... Rio Claro: Sociedade de Ecologia do Brasil, 2003. CD-ROM

PROCÓPIO, S. O. et al. Características fisiológicas das culturas de soja e feijão e de três espécies de plantas daninhas. Planta Daninha, v. 22, n. 2, p. 211-216, 2004.
PYSTINA, N. V.; DANILOV, R. A. Influence of light regimes on respiration, activity of alternative respiratory pathway and carbohydrates content in mature leaves of Ajuga reptans L. R. Bras. Fisiol. Veg., v. 13, n. 3, p. 285-292, 2001.

RADOSEVICH, S.; HOLT, J.; GHERSA, C. Weed ecology New York: John Willey \& Sons, 1997. 589 p.

SHARKEY, T. D.; RASCHKE, K. Effect of light quality on stomatal opening in leaves of Xanthium strumarium L. Plant Physiol., v. 68, n. 5, p. 1170-1174, 1981.

SMITH, H. Light quality, photoperception, and plant strategy. Ann. Rev. Plant Physiol., v. 33, p. 481-518. 1982.

TALLMAN, G.; ZEIGER, E. Light quality and osmoregulation in Vicia guard cells. Plant Physiol., v. 88, p. $887-895,1988$.

TILMAN, D. Resources: a graphical-mechanistic approach to competition and predation. Am. Natur., v. 116, p. 362-393, 1980.

VANDERZEE, D.; KENNEDY, R. A. Development of photosynthetic activity following anaerobic germination in rice-mimic grass (Echinochloa crus-galli var oryzicola). Plant Physiol., v. 73, p. 332-339, 1983.

WELLER, J. L.; MURFET, I. C.; REID, J. B. Pea mutants with reduced sensitivity to far-red light define an important role for phytochrome A in day-length detection. Plant Physiol., v. 114, n. 4, p. 1225-1236, 1997. 